\title{
Socio-ecological assessment for environmental planning in coastal fishery areas: A case study in Brazilian mangroves
}

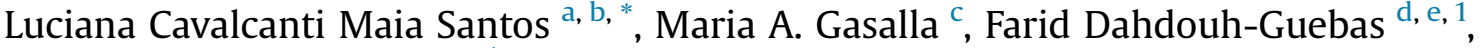 \\ Marisa Dantas Bitencourt ${ }^{\mathrm{a}, 1}$ \\ a Laboratório de Ecologia da Paisagem e Conservação (LEPaC), Universidade de São Paulo. Rua do Matão, 321, Travessa 14, Cidade Universitária, São Paulo, \\ SP, Brazil \\ ${ }^{\mathrm{b}}$ Universidade Estadual Paulista Júlio de Mesquita Filho - UNESP, Campus Registro. Av. Nelson Brihi Badur, 430, Vila Tupi, Registro, SP, Brazil \\ ${ }^{c}$ Laboratório de Ecossistemas Pesqueiros (LabPesq), Instituto Oceanográfico, Universidade de São Paulo. Praça do Oceanográfico, 191. Cidade Universitária, \\ São Paulo, SP, Brazil \\ d Laboratory of Systems Ecology and Resource Management, Université Libre de Bruxelles - ULB, CP 264/1, Avenue Franklin D. Roosevelt 50, B-1050, \\ Brussels, Belgium \\ e Laboratory of Plant Biology and Nature Management, Mangrove Management Group, Vrije Universiteit Brussel - VUB, Pleinlaan 2, B-1050, Brussels, \\ Belgium
}

\section{A R T I C L E I N F O}

\section{Article history:}

Received 11 July 2016

Received in revised form

21 November 2016

Accepted 7 January 2017

Available online 17 January 2017

\section{Keywords:}

Fishery

Management

Mangrove

Traditional populations

Sustainability

\begin{abstract}
A B S T R A C T
Along the world's (sub) tropics mangroves are important coastal ecosystems supporting small-scale fisheries and human populations, highlighting the need to consider participatory approaches in this ecosystem management. We carried out a socio-ecological assessment to characterize the use and perceptions of local populations at Northeastern Brazil (São Francisco River Estuary) on mangrove fisheries and local development, and pointed out strategies for environmental planning. The questionnaire-based results show that the locals are economically dependent on mangrove fisheries, exploring 12 types of fish, 4 types of crabs, 3 types of mollusks and shrimps. All populations indicated a decrease in the fishery yield, mainly due to a high fishery pressure and shrimp farming. We conclude that strategies pointed out by the locals as creation of an protected area of sustainable use (Extractive Reserve), aided by government support to create a local small-scale fishery processing industry, to cultivate oysters and fish and ecotourism are sustainable alternatives for poverty alleviation and mangrove conservation. These alternatives and the socio-ecological assessment should be a guideline for other mangroves areas worldwide with similar environmental problems and where fishery is the base of economic subsistence, in order to guarantees the long term sustainability of mangrove socio-ecological systems.
\end{abstract}

(C) 2017 Elsevier Ltd. All rights reserved.

\section{Introduction}

\subsection{Conceptual basis}

All humanly used resources are embedded in complex, socialecological systems (SESs), in which subsystems as resource system, resource units, users, governance systems and rules are relatively separable but interact to produce outcomes at the SES level,

\footnotetext{
* Corresponding author. Universidade Estadual Paulista Júlio de Mesquita Filho UNESP, Campus Registro. Av. Nelson Brihi Badur, 430, Vila Tupi, Registro, SP, Brazil. E-mail address: santos.lucianacm@gmail.com (L.C.M. Santos).

1 Co-last author.
}

demanding scientific knowledge that combine ecological and social sciences to enhance efforts to sustain SESs (Ostrom, 2009). Mangroves, coastal ecosystems distributed along the world's (sub) tropics, can be characterized as a good example of SESs, since their resources have been heavily traditionally used for food, timber, fuel, medicine and socio-economic subsistence (Rönnbäck, 1999; Alongi, 2002; Walters et al., 2008). This ecosystem supports diverse local fisheries including fishes, crustaceans (crabs, shrimps) and mollusks, which are source of income for traditional and deprived human communities (Rönnbäck, 1999; Walters et al., 2008; Satyanarayana et al., 2013; Santos et al., 2014). Positive correlations have been demonstrated between mangrove cover and municipal fisheries landings (Rönnbäck, 1999), thus, it is estimated 
that two-thirds of the world's fishing communities depend on the existence of mangroves (FAO, 2003).

Though the importance of mangrove ecosystems for human subsistence has been reported before (Rönnbäck, 1999; Saenger, 2002; Walters, 2003; Wattage and Mardle, 2005; FAO, 2007; Walters et al., 2008; Satyanarayana et al., 2013), research on the extent on which the livelihoods depend on certain resources is still lacking (Satyanarayana et al., 2013). Evaluation of the importance of mangroves for human communities and their knowledge about the ecosystem and fishery resources are important information for the local conservation and coastal management as well as for the maintenance of these communities and fishery stocks (e.g. Souto, 2007; Nordi et al., 2009; Firmo et al., 2011, 2012; Magalhães et al., 2012; Satyanarayana et al., 2013). In this context in which humans and environment are linked and interdependent, socioecological assessment is a major tool for coastal management, since it considers this relationship and local knowledge as important information for environmental planning. In this view, ethnozoology studies have been developing a chief importance, aiding in valorization of the regional fauna from an ecological point of view as well as from economic and social standpoints, and subsidize environmental management and species conservation plans that take into account the social and economic realities of the human populations that will be affected (Alves and Nishida, 2003; Alves, 2012; Alves and Souto, 2015). For example, many ethnozoological studies with fisher or harvesters of different mangrove resources as mollusks (e.g. Nishida et al., 2006a,b,c; Rocha et al., 2008), fishes (e.g. Rocha et al., 2008) and crabs (e.g. Alves and Nishida, 2002, 2003; Rocha et al., 2008; Capistrano and Lopes, 2012; Nascimento et al., 2012, 2016), have shown that local populations have a high knowledge of the species they depend upon and the environment, therefore, they can contribute for the establishment of management strategies (Alves and Souto, 2015). In Brasil, this is a really fact for the crab species Ucides cordatus, Cardisoma guanhumi and Callinectes sapidus, for which local knowledge was fundamental for the elaboration of a National Propose of Management Plan for these crabs (Brasil, 2011).

Co-management schemes, involving fishers and government agencies as partners, has been promising in the management of tropical coastal fisheries, as in the Caribbean and Pacific Islands (Warner, 1997; Zann, 1999; Johannes, 2002; Nishida et al., 2006c). The implementation of a successful management strategy fundamentally requires the involvement of the main stakeholders, who must be sensitized to the need for the conservation of the natural resource as a guarantee for its sustainable exploitation (Nishida et al., 2006c).

\subsection{Question of study}

Brazil, with a coastal zone of approximately $8500 \mathrm{~km}$ of extent $\left(4^{\circ} 30^{\prime} \mathrm{N}\right.$ to $\left.33^{\circ} 44^{\prime} \mathrm{S}\right)$, shows the second largest mangrove area in the world (Asmus and Kitzmann, 2004; Spalding et al., 2010). In this country artisanal fishery is fundamentally relevant because this activity produces food, for commercial purposes and a means of economic subsistence (Nishida et al., 2006a). The bulk of Brazilian fishery is based on mangrove ecosystems whose species spend most of their life cycle in those environments (Vannucci, 2002; Nishida et al., 2006a). A diversity of fishery resources are exploited in Brazilian mangroves, such as fish (e.g. Souto, 2008), mollusks (e.g. Nishida et al., 2006a, b; Mendonça and Machado, 2010) and crabs (e.g. Alves et al., 2005; Ferreira et al., 2009; Nordi et al., 2009; Firmo et al., 2012, 2011; Magalhães et al., 2012).

Although various decrees and laws legally enforce the conservation and management of Brazilian mangroves, the ecosystem have been affected by a variety of anthropogenic activities (Santos et al., 2014), resulting in environmental changes and socioeconomic impacts on the communities that depends on mangrove resources (e.g. Glaser, 2003). In this view, it is important to consider that the perception of environmental changes by local communities has proven valuable as a background to reconstruct historical use and impact on mangroves (Walters, 2003; DahdouhGuebas et al., 2004, 2005; Walters et al., 2008; Nfotabong-Atheull et al., 2011), serving as information and support for the local management and conservation efforts (e.g. Satyanarayana et al., 2013).

In Northeastern Brazil, the São Francisco River Estuary $\left(10^{\circ} 30^{\prime}\right.$ $\left.27^{\prime \prime} \mathrm{S}, 36^{\circ} 23^{\prime} 45^{\prime \prime} \mathrm{W}\right)$ comprises a significant mangrove area $\left(30 \mathrm{~km}^{2}\right)$ nearby human populations live and use mangrove fishery resources. Despite this, the economic and social importance of these resources and the knowledge and management practices of the local populations are poorly documented. Additionally, even though this area is part of a protected area where sustainable use is allowed (Sergipe, 2004), the poverty, decrease of fisheries resources and deforestation of mangroves for shrimp farming are constraints to achieve sustainability. Similar scenarios are found along Brazilian coast and worldwide wherein mangrove socioecological systems face impacts that put in risk its long term sustainability (e.g. Dahdouh-Guebas et al., 2005; FAO, 2007; Firmo et al., 2011; Satyanarayana et al., 2013). This study aims to characterize the use of economic important mangrove fishery resources by the human populations of the São Francisco River Estuary, and their perceptions on the mangrove fisheries shifts and environmental impacts that occurred during the last decade as well as their perspectives for community sustainable development. Our hypothesis is that mangrove fisheries are the unique source for local economic subsistent and this high dependence conducted to a high development of local knowledge on the environment and changes/ impacts, which can aid in formulating management strategies for socio-ecological sustainability. Therefore, based on the data generated in this study, we pointed out some strategies important to be considered in the local management. The applicability of these management strategies and socio-ecological assessment were also discussed for the national scale and for mangrove areas worldwide with similar characteristics and environmental problems. Therefore, we contribute with important information and methodology for environmental planning and management in mangrove coastal areas.

\section{Material and methods}

\subsection{Study area}

The São Francisco River is one of the most important and largest Brazilian water resources and is considered the River of National Integration, draining seven states along its $2863 \mathrm{~km}$ with a river basin of $636,919 \mathrm{~km}^{2}$ (ANA, 2005, Fig. 1a; b). The estuary of this river is located in the low São Francisco, on the boundary of Sergipe and Alagoas States $\left(10^{\circ} 30^{\prime} 27^{\prime \prime} \mathrm{S}, 36^{\circ} 23^{\prime} 45^{\prime \prime} \mathrm{W}\right)$ in the Northeast of Brazil (Fig. 1b and c). The study area corresponds to the southern part of this Estuary (State of Sergipe) (Fig. 1c) and covers approximately $192.35 \mathrm{~km}^{2}$ and is part of the municipalities of "Brejo Grande" and "Pacatuba". About 93\% of the study area is occupied by natural cover such as: sandy coastal vegetation (77\%), mangroves (15.7\%) and intertidal flats (0.7\%), while $7 \%$ is occupied by human activities as aquaculture (2.4\%) and agriculture (4.7\%) (Santos et al., 2014).

The study area is part of a State Environmental Protected Area (APA "Litoral Norte"), a conservation unit of sustainable use which was created in 2004, but still does not have a Management Plan (Sergipe, 2004; Santos et al., 2014). This area is characterized by a 


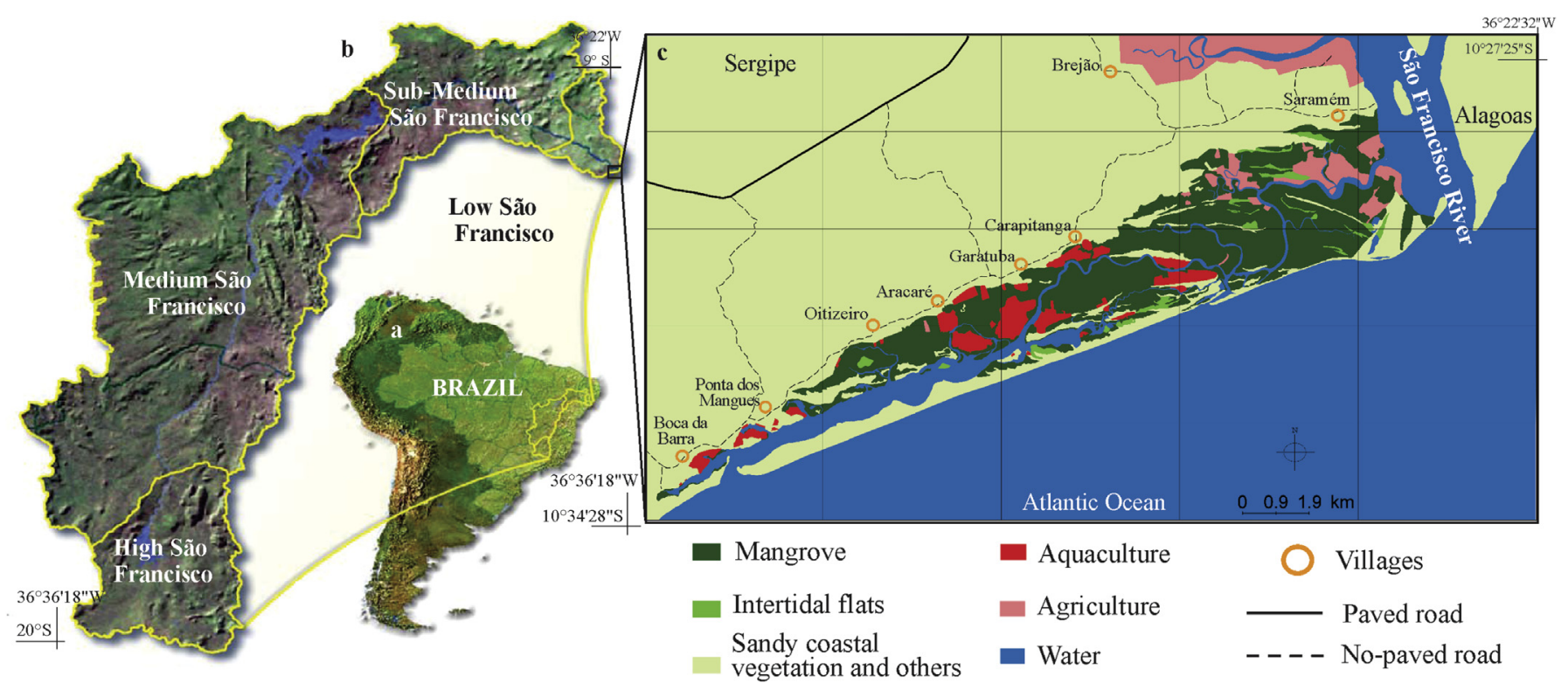

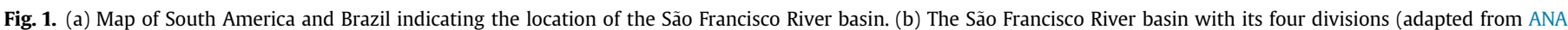
2005). (c) A close-up of the São Francisco River Estuary, the study area (adapted from Santos et al., 2014).

remarkable lack of public infrastructure, such as paved roads, hospital, health centre, schools and commercial services. The inhabitants are distributed along eight small villages located parallel to the mangrove forests (Fig. 1c) and they are deprived population composed of native residents showing low human development indices (0.584 and 0.550) (PNUD, 2013).

\subsection{Data collection in the coastal villages}

On January 2013 fieldworks were carried out in order to collect data about the use of economic important mangrove fishery resources (fish, crabs, shrimps and mollusks) by the human populations of the São Francisco River Estuary, their perceptions on the mangrove fisheries shifts that occurred during the last 13 years and their perspectives for local development. We considered the period of 13 years in order to compare the responses of the interviews with the available data of statistic fishery in the region. Five coastal villages were sampled (Table 1, Fig. 1c) because they are the most important in terms of fishery and crab production. The sampling of the interviews was random, and a native inhabitant acted as local mediator (e.g. Albuquerque et al., 2014a). Only local specialists (e.g. Albuquerque et al., 2014a), i.e., people that use or used mangrove fishery resources were interviewed. Additionally, the snowball technique (Goodman, 1961) was also applied.

We applied structured interviews (e.g. Albuquerque et al., 2014b) which were digitally recorded, filmed and photographed, when the interviewees allowed. We were precluded from adopting

Table 1

Villages sampled in the fieldwork, its geographic coordinates and the number of people interviewed.

\begin{tabular}{lll}
\hline Village & $\begin{array}{l}\text { Geographic coordinates }(\mathrm{X}, \\
\mathrm{Y})\end{array}$ & $\begin{array}{l}\text { Number of people } \\
\text { interviewed }\end{array}$ \\
\hline $\begin{array}{l}\text { Boca da Barra } \\
\text { Ponta dos }\end{array}$ & $762,935.64,8,830,727.85$ & 5 \\
$\quad$ Mangues & $765,479.59,8,832,323.99$ & 11 \\
Oitizeiro & $768,539.97,8,834,633.41$ & 10 \\
Aracaré & $770,524.58,8,835,375.34$ & 10 \\
Carapitanga & $774,240.62,8,837,120.08$ & 12 \\
\hline
\end{tabular}

a formal approach using interview consent forms, due to the poor level of organization of the communities and high illiteracy rates (e.g. Alves et al., 2005; Firmo et al., 2011). The interviews were individual and collective in focal groups with number varying from two to six people. The interviews contained open-ended, yes/no and multiple choice questions. A total of 48 inhabitant were interviewed, with the participation of 35 men (73\%) and 13 women (27\%) whose ages ranged between 18 and 73 . This represents $16 \%$ of the local human population within the five villages, which is a significant number, calculated based on the population density (IBGE, 2010) of the municipalities of Pacatuba and Brejo Grande. For these villages, there is no official sense of the number of residents.

\subsection{Data analysis}

All digitally recorded interviews were transcribed. The data were analyzed qualitatively, using the union model (Marques, 1991), in which all information collected on the interviews was considered. After that, the responses were categorized and tabulated in Excel spreadsheets. The $\chi^{2}$ test was used to compare the frequencies of respondents among the fishery villages, and it was carried out in the GraphPad Prism software. We applied this test in order to verify if the response given by the interviewees in each village are statically different. The information provided by the participants was compared with those from the specialized academic literature, following ethnoscientific notions with a balance between emic and etic focused approaches (Sturtevant, 1964; Magalhães et al., 2012).

\section{Results and discussion}

\subsection{Mangrove fishery resources and socio-economic importance}

Different mangrove-fishery resources are exploited by the coastal communities of the São Francisco River Estuary. Fish are the most exploited resources, followed by crabs, mollusks and shrimps (Fig. 2a). About $88 \%$ of the interviewees explore at least two different types of fishery resources, and $75 \%$ explore almost all mangrove-fishery resources. Therefore, they execute both activities 

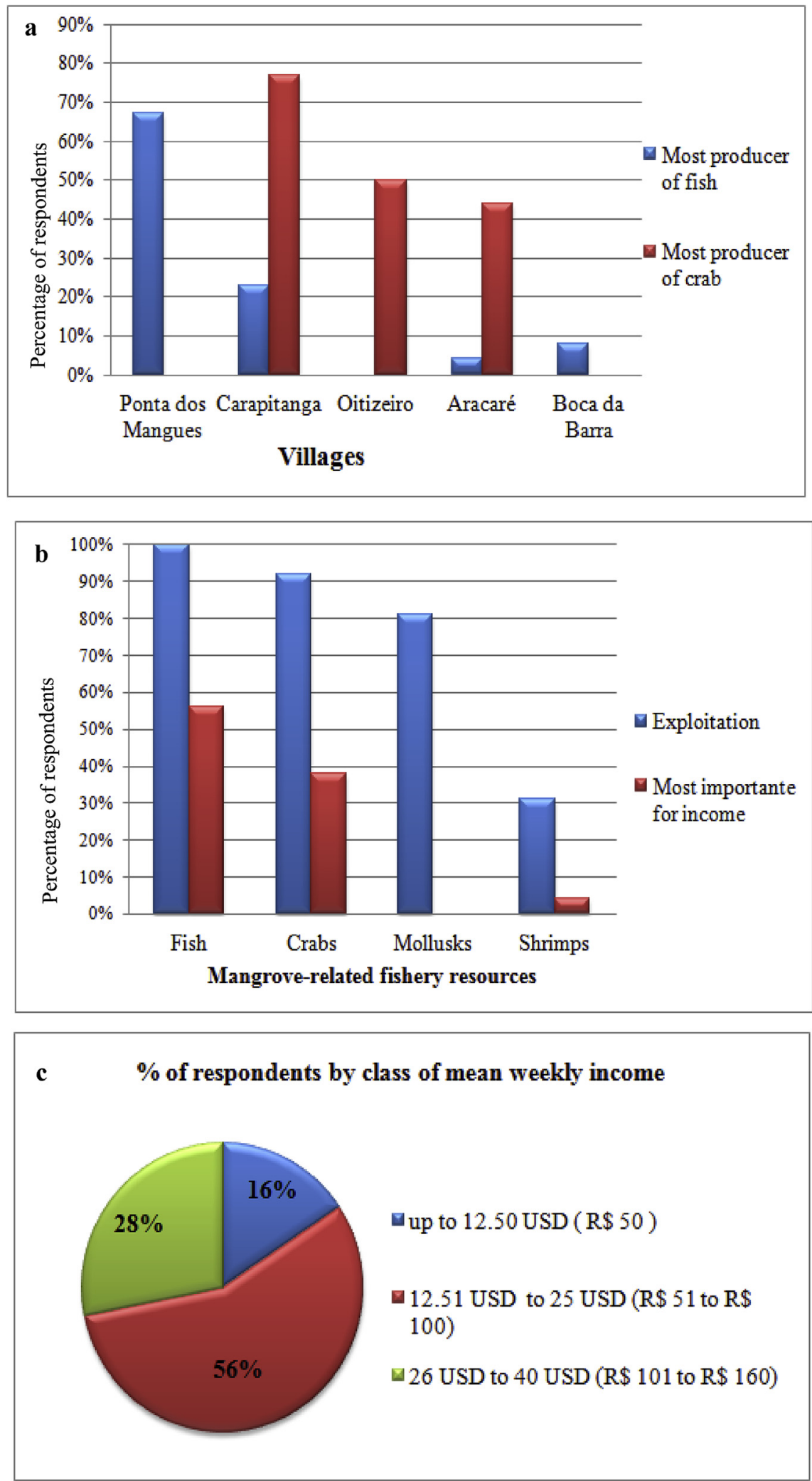

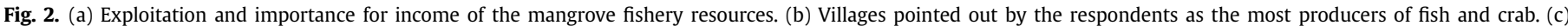

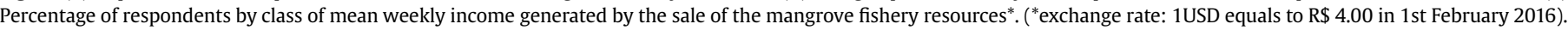

of fishers and gathers of crabs and mollusks (Fig. 3). Currently 90\% of the interviewees primarily depend on the mangrove fishery resources for their economic subsistence and $10 \%$ depended on the past.

These results show how the economic subsistence and life of the coastal communities of the São Francisco River Estuary rely on the 


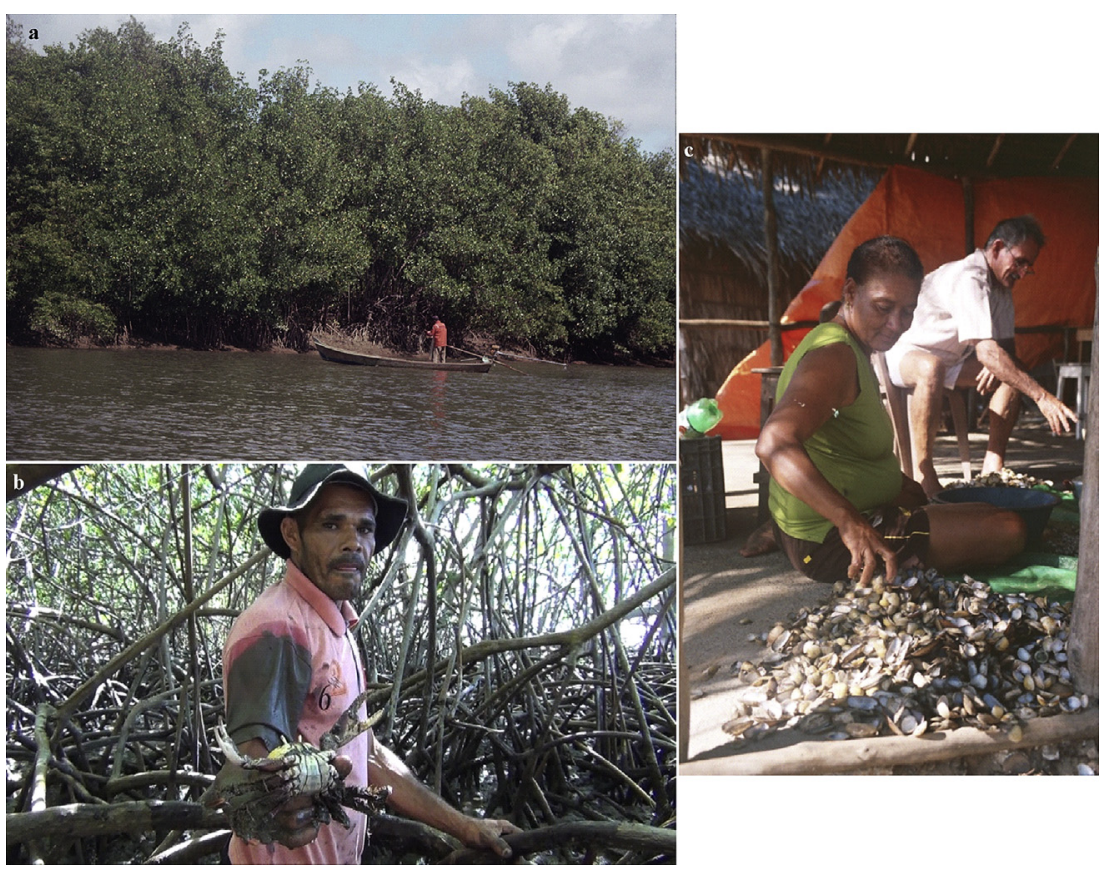

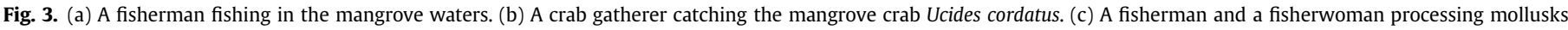
collected in the mangrove.

Table 2

Mangrove related fish used by the local populations of the São Francisco River Estuary and percentage (\%) of respondents that use this type of resource.

\begin{tabular}{lll}
\hline Familly & Species or gender & Vernacular name \\
\hline Mugilidae (mullets) & Mugil sp. & "tainha" \\
& Mugil liza & "curimã" \\
Centropomidae (snooks) & Centropomus sp. & "robalo" \\
& Centropomus ensiferus & "camurim" \\
Gerreidae (mojarras) & Diapterus rhombeus & "carapeba" \\
& Eugerres brasilianus & "tinga" \\
Ariidae (catfish) & Arius sp.; Bagre sp. & "bagre" \\
Lutjanidae (snappers) & Lutjanus synagris & "vermelha" \\
Sciaenidae & Cynoscion leiarchus & "pescada" \\
Cichlidae & Geophagus brasiliensis & "cará" \\
\hline
\end{tabular}

mangrove environment and fishery resources. As found in other coastal communities worldwide, mangrove ecosystems feature a high biomass and biodiversity concentration characterized by abundance of fish, crustaceans and mollusks, which constitutes fisheries of major value of marketed natural resources, supporting the exploitation by many traditional populations that survive on it (Hamilton et al., 1989; Rönnbäck, 1999; Walters et al., 2008; Souto, 2008). In this study we recorded a high exploitation of this diversity, wherein all mangrove fishery resources are exploited by the local populations (Fig. 2b).

We recorded a significant difference among the most producer villages in relation of the fishery product, wherein the village of "Ponta dos Mangues" is the most producer of fish differing from "Carapitanga", "Oitizeiro" and "Aracaré", which are most producer of the crab Ucides cordatus $\left(\chi^{2}=86.9, \mathrm{p}<0.0001\right.$, Fig. $\left.2 \mathrm{a}\right)$.

Fish are the most important source of income for the local populations (Fig. 2b). The interviewees pointed out about 10 types of fish caught in the waters of the mangroves (Table 2). Among them, Mugil sp. is the most harvest and indicated as the principal and more abundant fish in the mangroves (Table 2). Centropomus $\mathrm{sp}$. is the second most exploited followed by Diapterus rhombeus and fish from the family Ariidae (Table 2). Less exploited fish are Eugerres brasilianus, Lutjanus synagris, Cynoscion leiarchus and
Geophagus brasiliensis (Table 2). Fish was the most diverse and exploited group probably due to it higher market value than the other resources, especially for snooks (Centropomus sp.), and due to their high abundance, particularly for mullets which is the most conspicuous fish group in mangroves (Christesen, 1983) with high use value in coastal communities (e.g. Rocha et al., 2008; Pinto et al., 2015). Lacerda (2002) have reported that these two groups are the most commercial important in the Brazilian mangroves. Additionally, all the fish species exploited by the coastal populations of the São Francisco River Estuary are among fish families that utilize mangroves as habitat and are of economic importance (e.g. Rönnbäck, 1999). Majority of the fish groups (e.g. mullets, snooks, mojarras, catfish, snappers) was also recognized as fish from mangroves and estuarine areas by other local populations along the Brazilian coast, especially in Northeast (e.g. Rocha et al., 2008; Souto, 2008; Pinto et al., 2015), highlighting its commercial importance.

From crustaceans, crabs are more exploited than shrimps (Fig. 2b). Four different types of crabs were pointed out by the respondents (Table 3). Among them, the most exploited is Ucides cordatus which constitutes the second most important source of income for the local residents (Table 3, Fig. 2b). In the villages of Carapitanga, Oitizeiro and Aracaré, $U$. cordatus constitutes the base 
Table 3

Mangrove related crabs used by the local populations of the São Francisco River Estuary, and percentage (\%) of respondents that use this type of resource.

\begin{tabular}{llll}
\hline Familly & Species or gender & Vernacular name & \% of Respondents \\
\hline Ucididae & Ucides cordatus & "caranguejo" & 88 \\
Portunidae & Callinectes spp. & "siri" & 48 \\
Grapsidae & Goniopsis cruentata & "aratu" & 35 \\
Gecarcinidae & Cardisoma guanhumi & "guaiamum" & 31 \\
\hline
\end{tabular}

of the local subsistence economy (Fig. 2a). The species of crabs exploited by the locals of the São Francisco River Estuary are among the most important crustacean captured and commercialized in Brazil (e.g. Alves et al., 2005; Souto, 2007; Firmo et al., 2012). Nevertheless, it is remarkably the highest exploitation and the economic importance of $U$. cordatus. One of the facts that can contribute for this, is that the mangrove crab constitutes a typical dish in the cuisine of Brazil Northeast, specially, in Sergipe State, where it is considered an identity of the local gastronomy. Similarly, other studies also have documented the importance of $U$. cordatus as fishing resource and source of income and employment for the communities residing in the vicinity of Brazilian estuaries (e.g. Glaser, 2003; Souto, 2007, 2008). Thus, this crab species has a significant socioeconomic importance and significant poverty alleviation function in the coast of Brazil, particularly, in the North and Northeast (Glaser and Grasso, 1998; Glaser, 2003; Alves and Nishida, 2002, 2003).

Native shrimps that naturally occur associated to the mangrove environment (e.g. Litopenaeus schimitti, Farfantepenaeus subtilis e Xiphopenaeus kroyeri) are the least exploited resources, and are important source of income for only $4 \%$ of the interviewees (Fig. 2b). The respondents pointed out that since the activity of aquaculture of the exotic shrimp species Litopenaeus vannamei have started in the study area, the fishery of native shrimps drastically reduced. Due to competition with this activity that starts in ends of the 90's (Santos et al., 2014), local fishermen stop the exploitation of native fish shrimps, and nowadays few locals develop this fishery. This activity when carried out without adequate management, as occur in the study area (e.g. Santos et al., 2014) can cause socioeconomic impacts as loss of fisheries livelihoods (Primavera, 2006). Not only in Brazil, but also worldwide, shrimp farming has been point as one of the main anthropogenic activity responsible for the conversion and degradation of mangrove forests (Alongi, 2002; Primavera, 2006; FAO, 2007).

Mangrove estuarine areas often support an abundance of mollusk species that are largely sessile in nature and constitute an important in-situ fishery (Macnae, 1974; Macintosh, 1982; Matthes and Kapetsky, 1988; Nishida et al., 2006b). From the mollusks, the mangrove oyster Crassostrea rhizophorae is the most exploited followed by Mytella sp., and the least harvest is Anomalocardia brasiliana (Table 4). These three species of mollusks collected in the mangroves of the study area are among the most prominent in artisanal fishery of Brazilian mangroves (e.g. Nishida et al., 2006a; Souto, 2008). Although these mollusks are the third most exploited resource in the study area, due to their low market value in the region they were not account as major importance for income

Table 4

Mangrove related shellfish used by the local populations of the São Francisco River Estuary, and percentage (\%) of respondents that use this type of resource.

\begin{tabular}{llll}
\hline Familly & Species or gender & Vernacular name & \% of Respondents \\
\hline Ostreidae & Crassostrea rhizophorae & "ostra" & 67 \\
Mytilidae & Mytella sp. & "sururu" & 63 \\
Veneridae & Anomalocardia brasiliana & "maçunin" & 21 \\
\hline
\end{tabular}

generation (Fig. 2b).

Most of the fishers (40\%) sell the fish, crabs, shrimps and mollusks in the local market, although others (30\%) sell for intermediate buyers. These intermediates buy the fishery products at low prices and sell it in other places, as in the capital city Aracaju, at higher prices. The average earnings obtained by the sale of the fishery per individual fisherman reaches less than 25 USD per week (Fig. 2c), being not fixed and usually lower. This value is lower when compared with the current weekly figure of the minimum Brazilian wage which correspond to about 55.5 USD (R \$ 220).

\subsection{Local perceptions on fishery shifts and environmental impacts}

Local people generally will observe changes in the ecosystem where they live if this results in an increase or decrease production of resources (Ward et al., 2000; Satyanarayana et al., 2013). In the study area, due to a high relationship and economic dependence on mangrove fishery resources, changes undergone in fishery yield and causes for it were wildly perceived by the local populations (Fig. 4a and b). Among the fishery products exploited by the local populations, the crab Ucides cordatus was, unanimously, the most indicated resource with decrease in yield during the last 13 years (Fig. 4a). Fish in general was also highly indicated (Fig. 4a).

Different causes for fishery decrease were pointed out by the locals, with frequencies which did not statistical differed (Fig. 4b; $\chi^{2}=14.37, \mathrm{p}=0.072$ ). The main cause for decrease in fishery yield was the high number of fishers, which lead to overcapacity/overexploitation of the fishery resources (Fig. 4b). This reflects the lack of jobs and alternative income in the study area, a social problem not only for the local subsistence but also for the sustainable use of the mangrove resources.

Shrimp farming was the second main reason indicated as the cause for the fishery decrease (Fig. 4b), especially for the crab Ucides cordatus. Almost all interviewees said that the stock of $U$. cordatus drastically reduced (Fig. 4a), with one period of about one year and a half, between 2000 and 2001, just after the beginning of the shrimp farming activities, when the crabs were found dead in their burrows. According to some respondents, the chemical products used in the shrimp farming were released in the mangrove waters killing the crabs. This information is reinforced by the founds of Carvalho (2004) who reported that the effluents from this activity are released directly into the estuary. The pollution of coastal ecosystems greatly affects human communities along the shore which are used to living in harmony with these environments (Diegues, 1999), and local people are in overall concerned that water pollution can cause massive fish mortality (e.g. Satyanarayana et al., 2013). Moreover, the locals pointed out that for the installation of shrimp farming enterprises many mangrove forests were deforested, reducing the areas for fishing and the crab stock.

The third reason most indicated for the fishery fall was the decrease of the river floods, caused by the built of dams upstream the study area (Fig. 4b). According to the local people, the river floods did not occur after the functioning of the Xingó dam in 1994, the closest to the study area. They said that when there were the floods, they used to catch fish and shrimps in abundance, and after the dam the fish yield reduced. They attribute this to the lack of water because the dams hold it, and thus, the fish cannot come because there is not enough water. Corroborating with the information of the locals, studies have shown that the river flow, suspended and organic matter as well as nutrients have reduced after the Xingó dam (e.g. Knoppers et al., 2006), which may impacted the fish communities and contributed to the fishery decrease. Moreover, studies have reported that the regularization of the river flow, caused by dams, can affect fish migration and breeding in 

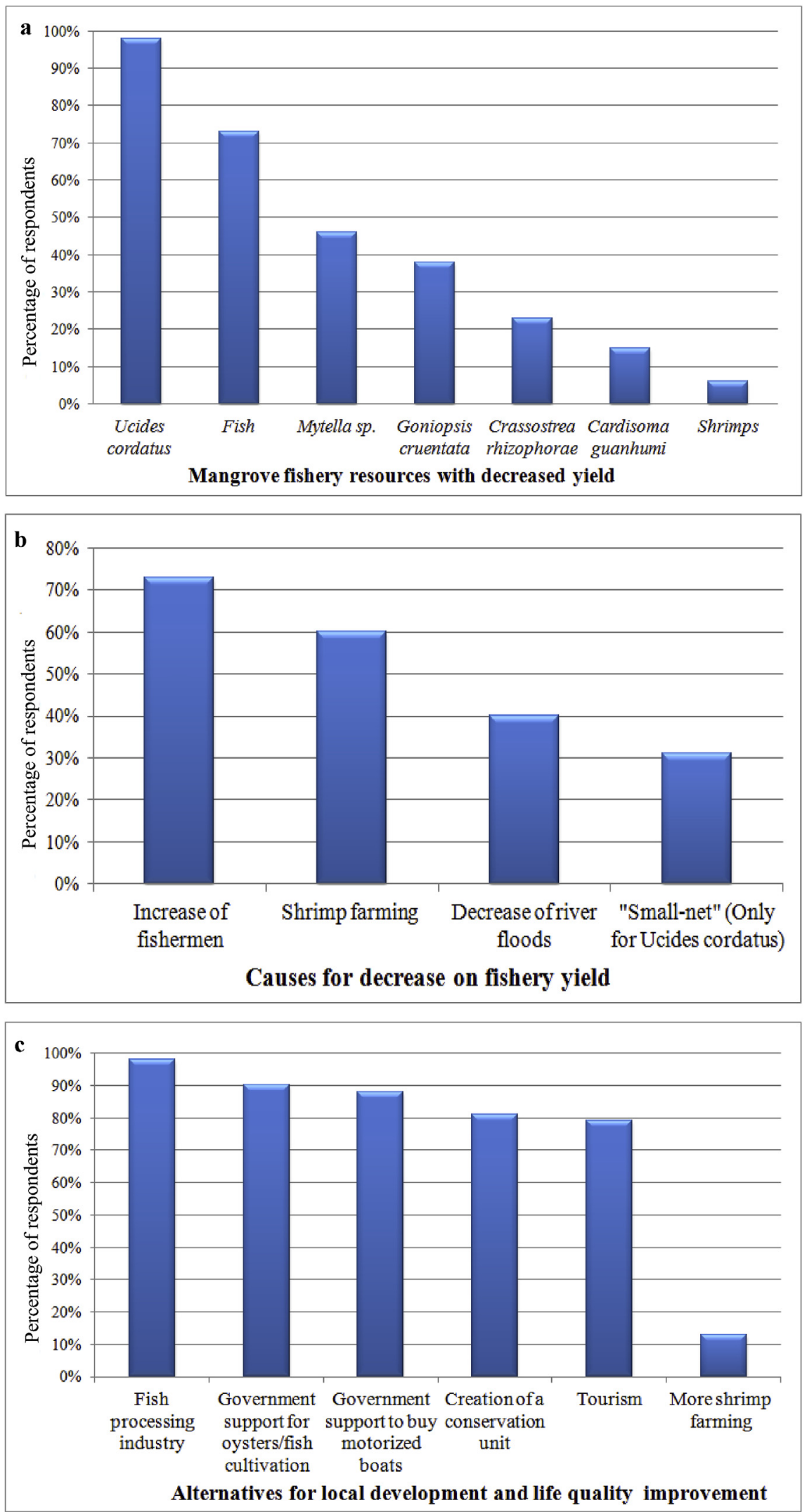

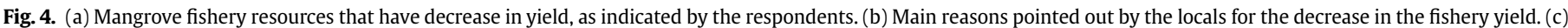
Alternatives pointed out by the respondents for local development and life quality improvement.

mangrove areas (e.g. Dahdouh-Guebas et al., 2010), and dynamic shifts in mangrove vegetation to reduced fish production in the vicinity (Satyanarayana et al., 2013).

A minor number of people indicated that the gather technique 
called "small-net" ("redinha") applied to catch the crab U. cordatus, as cause for the reduction of this crab fishery yield (Fig. 4b), which was statistically inferior than increase in the number of fisherman, decrease of the river floods and shrimp farming $\left(\chi^{2}=9.65\right.$, $\mathrm{p}=0.046 ; \chi^{2}=16.6, \mathrm{p}=0.002 ; \chi^{2}=9.86, \mathrm{p}=0.019$, respectively). In this technique the crab gather made a trap using nylon yarns from plastic bags and put it directly, or use branches of mangrove trees, in the burrow entrance of the crabs. Part of the respondents pointed out that the "small-net" catch the females and the small crabs, reducing the crab stock. Additionally, in agreement with the perceptions of some fishermen, the "small net" is legally prohibited in Brazil (IBAMA, 2003a, b), because it is less selective in the crab capture (Côrtes et al., 2014), and results in greater harvesting pressure (Nascimento et al., 2016).

\subsection{Population suggestions for the local development and life quality improvement}

When asked about the possibilities for the local development and life quality improvement all respondents pointed out that the introduction of a small-scale industry to process the fishery resources will be the best alternative (Fig. 3c). They stated that this industry will be an alternative of job for them for which they will sell the fishery products. The second and third most indicated alternatives were the support of government to cultivate native oysters and fish, which will be an alternative of income and to buy motorized boats which will allow them to explore other mangroves area far from the villages (Fig. 4c). At first glance these alternatives can been see as contradictory with the local reality of decrease of fishery resources. Nevertheless, when we consider the large extent of mangrove forests $\left(30 \mathrm{~km}^{2}\right.$, Santos et al., 2014) in the study area, which can lead for the implementation of extractive and fishery exclusion areas, with cotes of capture (Santos et al., 2016, Brasil, 2011; Pinheiro and Rodrigues, 2011), these are potential alternatives for local development based on a sustainable fishery management and use.

For example, the small-scale fishery processing industry besides be an new alternative of jobs, it is also important to break the dependence of the fishermen on intermediate buyers, which put the local population in an extreme disadvantage, with low profit and dependence on the intermediates buyers. A similar situation was also found by Alves et al. (2005), in the coastal communities of the Mamanguape River, (Paraíba State, Northeast Brazil), where the crab gatherers economically depended on buyers, who are therefore in a position to explore them. In regard to government support to cultivate native oysters and fish, the study area shows potential for this, especially in mangrove-friendly aquaculture practices of the mangrove oyster Crassostrea sp. and native fish species (Santos et al., 2014). Mangrove-friendly aquaculture is developed in the mangrove waters without deforestation and is a socio-sustainable practice (Primavera, 2006). The government support to buy motorized boats is somewhat controversial for the ecological sustainability. On the one hand it will allow the locals to explore other mangrove areas far from the villages, and, therefore reducing the fishery pressure on one single area. Additionally, it will allow the locals better working conditions, because in the currently situation, the fishermen reach the mangrove areas by canoe, mainly without motor, or by foot. On the other hand, there is the possibility of increasing the fishing effort on mangroves which are nursery areas of fishery resources. In this context, it is important to underline that a limitation of the range of vessels may also be a strategy of conservation, as well as the mapping of mangrove areas for fishery and for conservation of the resource, as carried out in our previous study for the mangrove crab U. cordatus (Santos et al., 2016).

Creation of a conservation unit of sustainable use and tourism were the fourth and fifth alternatives indicated (Fig. 4c). Although most locals (81\%) agreed with the first alternative, and stated that it is possible a combination of the mangrove resource exploitation and areas of conservation, few (19\%) point out that it is not possible to conserve the mangroves, because they do not have another source of income to survive unless to explore these resources. Remarkably, the introduction of more shrimp farming is not seemed as a good alternative for local development. Only few people indicate this activity as important, stating that it will be source of job for them (Fig. 4c). This figure pattern of suggestions did not statistically differ among the five fishery villages $\left(\chi^{2}=20.4\right.$, $\mathrm{p}=0.43$ ), indicating a homogeneous perceptions among the villages.

Currently, about $77 \%$ of Brazilian protected mangroves are situated in protected areas of sustainable use (Magris and Barreto, 2010), which aims to combine the conservation and use of mangrove resources by human population. Although the study area is part of a large conservation unit of the category environmental protected area (APA) since 2004, we identified that the socio-local characteristics of the region wherein local populations rely on mangrove fishery exploitation, best fit this area in a conservation unity of the category "Extractive Reserve", according to the characteristics and objectives pointed out in the Brazilian National System of Conservation Units - SNUC (Brasil, 2000). The Extractive Reserve is an area used by traditional extractive populations, whose livelihood is based on the extractive activities, and its basic objectives are to protect the livelihoods and culture of these populations, and ensuring the sustainable use of natural resources of the unit (Brasil, 2000).

To summarize, based on the local reality and perceptions, we recommend the implementation of a Extractive Reserve in the study area, based on the sustainable use of the fishery resources by fishery management plans, mapping of fishery and exclusion areas and capture cotes. Considering these points, it is also possible to consider the government support for local organization to create a small-scale fishery processing industry, to cultivate native oysters and fish, and to buy motorized boats, in order to promote social development and poverty alleviation. Additionally, the ecotourism, which can use as attractive the local gastronomy with typical dishes based on mangrove fishery resources, can be also encouraged and supported by the government agencies and environmental managers, in order to generate more jobs for the locals. These strategies should be considered in an integrative and synoptic view, with the local participation, as part of a management plan for the creation of an Extractive Reserve.

Developing sustainable management policies that also consider the subsistence requirements of local people, is a high priority (Dahdouh-Guebas et al., 2006). For this, the integration of indigenous knowledge into contemporary frameworks for conservation and sustainable management of natural resources is become increasingly important in policies on an international and national level (Dahdouh-Guebas et al., 2006). Here we find that is extremely important to consider a participatory approach of the local population in order to meet the objectives of the local and National mangrove environmental protected areas. The strategies suggested here can be applied in other mangrove areas, in Brazil or worldwide, with similar characteristics, which can be evaluated by a similar environmental assessment applied in this study. Here we bring new management strategies (introduction of a small-scale fishery processing industry, government support to cultivate native oysters and fish and to buy motorized boats and ecotourism) that aim to combine mangrove conservation and its fishery resource use in a sustainable way in socio-ecological systems. 


\section{Conclusion}

We conclude that mangrove fisheries are the main economic subsistence base of the coastal communities on the São Francisco River Estuary, a reality found along the Brazilian coast and in mangroves worldwide, charactering this ecosystem as complex socio-ecological system, wherein people and natural resources are totally interdependent. These found stress the need to consider participatory approaches, including local populations, researchers and governmental environmental agencies, for coastal management and environmental planning in mangrove fishery areas, which can be archived by socio-ecological assessment tools.

Here we conclude that strategies pointed out by the locals to improve their livelihood, mainly the creation of a protected area of sustainable use based on the rational exploitation of mangrove fishery resources (Extractive Reserve), aided by government support to create a local small-scale fishery processing industry, to cultivate oysters and fish and ecotourism are good sustainable alternatives for poverty alleviation and should be considered for the local environmental planning. These alternatives and the socioecological assessment should also be a guideline for other mangroves areas worldwide with similar environmental problems and where fishery is the base of economic subsistence, in order to find ways to guarantee the long term sustainability of the socioecological system.

\section{Acknowledgments}

This study was undertaken with the financial support of FAPESP (Fundação de Amparo à Pesquisa do Estado de São Paulo, Grant number \# 2010/20028-9). We are grateful to ICMBio/Projeto Tamar (Pirambu/SE, Brazil), Prof. Dr. Humberto Reis Matos (Universidade Federal de Sergipe), Rafael dos Santos (Projeto Tamar Ponta dos Mangues/SE, Brazil), Givaldo de Jesus and Evaldo dos Santos (native fishermen of Ponta dos Mangues) for their logistic support in the fieldworks. We would thank the anonymous reviewers for their important suggestions and comments in the review process of this manuscript.

\section{References}

Albuquerque, U.P., Ramos, M.A., Lucena, R.F.P., Alencar, N.L., 2014a. Methods and techniques used to collect ethnobiological data. In: Albuquerque, U.P., Cunha, L.V.F.C., Lucena, R.F.P., Alves, R.R.N. (Eds.), Methods and Techniques in Ethnobiology and Ethnoecology. Springer, New York, p. 1537.

Albuquerque, U.P., Cunha, L.V.F.C., Lucena, R.F.P., Alves, R.R.N., 2014b. Methods and Techniques in Ethnobiology and Ethnoecology. Springer, New York, p. 1537.

Alongi, D.M., 2002. Present state and future of the world's mangrove forests. Environ. Conserv. 29, 331-349.

Alves, R.R.N., 2012. Relationships between fauna and people and the role of ethnozoology in animal conservation. Ethnobiol. Conserv. 1, 169

Alves, R.R.N., Nishida, A.K., 2002. A ecdise do caranguejo-uçá, Ucides cordatus L. (Decapoda, Brachyura) na visão dos caranguejeiros. [The ecdise of the crab-uçá, Ucides cordatus L. (Decapoda, Brachyura) in the view of the crab gatherers]. Interciencia 27, 110-117 (In Portuguese).

Alves, R.R.N., Nishida, A.K., 2003. Aspectos socioeconômicos e percepção ambiental dos catadores de caranguejo-uçá Ucides cordatus cordatus (L. 1763) (Decapoda, Brachyura) do estuário do Rio Mamanguape, Nordeste do Brasil. Interciencia 28, 36-43 [Socio-economic aspects and environmental perception of the Ucides cordatus cordatus (L. 1763) (Decapoda, Brachyura) collectors of the Mamanguape River estuary, Northeast Brazil] (In Portuguese).

Alves, R.R.N., Souto, W.M.S., 2015. Ethnozoology: a brief introduction. Ethnobiol. Conserv. 4, 113.

Alves, R.R.N., Nishida, A.K., Hernandez, M.I.M., 2005. Environmental perception of gatherers of the crab 'caranguejo-ucá' (Ucides cordatus, Decapoda, Brachyura) affecting their collection attitudes. J. Ethnobiol. Ethnomed. 1, 10.

ANA- Agência Nacional de Águas, 2005. Plano decenal de recursos hídricos na bacia hidrográfica do Rio São Francisco (2004-2013) [Ten-year plan for water resources in the Basin of the São Francisco River]. Ministério do Meio Ambiente, Brasília (In Portuguese).

Asmus, M.L., Kitzmann, D., 2004. Gestão costeira no Brasil: estado atual e perspectivas [Coastal management in Brazil: current status and prospects]
Montevideo: EcoPlata. (In Portuguese).

Brasil. 2000. Lei no 9.985, de 18 de Julho de 2000. SNUC - Sistema Nacional de Unidades de Conservação. [Law \# 9985 of 18 July 2000. SNUC - National System of Protected Areas]. (In Portuguese).

Brasil, 2011. Proposta do Plano Nacional de Gestão para o uso sustentável do Caranguejo-Uçá, do Guaiamum e do Siri Azul. Instituto Brasileiro do Meio Ambiente e dos Recursos Naturais Renováveis (IBAMA), Brasília (DF) [Proposal of National Management Plan for the sustainable use of the Crab-Uçá, Guaiamum and Blue Crab]. (In Portuguese).

Capistrano, J.F., Lopes, P.F.M.L., 2012. Crab gatherers perceive concrete changes in the life history traits of Ucides cordatus (Linnaeus, 1763), but overestimate their past and current catches. Ethnobiol. Conserv. 1, 12.

Carvalho, M.E., 2004. A carcinicultura na zona costeira do estado de Sergipe [The shrimp farming in the coastal zone of SergipeSstate]. Master Thesis. Federal University of Sergipe, São Cristóvão, Brazil (In Portuguese).

Christesen, B., 1983. Mangrove: what are they worth? Unasylva 35, 2-15.

Côrtes, L.H.O., Zappes, C.A., Di Beneditto, A.P.M., 2014. Ethnoecology, gathering techniques and traditional management of the crab Ucides cordatus Linnaeus, 1763 in a mangrove forest in south-eastern Brazil. Ocean Coast. Manag. 93, $129-138$.

Dahdouh-Guebas, F., Van Pottelbergh, I., Kairo, J.G., Cannicci, S., Koedam, N., 2004 Human-impacted mangroves in Gazi (Kenya): predicting future vegetation based on retrospective remote sensing, social surveys, and distribution of trees. Mar. Ecol. Prog. Ser. 272, 77-92.

Dahdouh-Guebas, F., Hettiarachchi, S., Sooriyarachchi, S., Lo Seen, D., Batelaan, O. Jayatissa, L.P., Koedam, N., 2005. Transitions in ancient inland freshwater resource management in Sri Lanka affect biota and human populations in and around coastal lagoons. Curr. Biol. 15, 579-586.

Dahdouh-Guebas, F., Collin, S., Lo Seen, D., Rönnbäck, P., Depommier, D. Ravishankar, T., Koedam, N., 2006. Analysing ethnobotanical and fishery-related importance of mangroves of East-Godavari Delta (Andhra Pradesh, India) for conservation and management purposes. J. Ethnobiol. Ethnomed. 2, 24.

Dahdouh-Guebas, F., Koedam, N., Satyanarayana, B., Cannicci, S., 2010. Human hydrographical changes interact with propagule predation behaviour in $\mathrm{Sr}$ Lankan mangrove forests. J. Exp. Mar. Biol. Ecol. 399, 188-200.

Diegues, A.C., 1999. Human populations and coastal wetlands: conservation and management in Brazil. Ocean Coast. Manag. 42, 187-210.

FAO - Food and Agriculture Organization of the United Nations, 2003. Status and Trends in Mangrove Area Extent Worldwide. Forest Resources Assessment Working Paper No. 63.

FAO - Food and Agriculture Organization of the United Nations, 2007. The World's Mangrove 1980-2005. FAO. Forestry Paper, nº 153.

Ferreira, E.N., Mourão, J.S., Rocha, P.D., Nascimento, D.M., Bezerra, D.M.M., 2009 Folk classification of the crabs and swimming crabs (Crustacea-Brachyura) of the Mamanguape river estuary, Northeastern - Brazil. J. Ethnobiol. Ethnomed. 5,22 .

Firmo, A.M.S., Tognella, M.M.P., Có Walter, L.O., Barboza, R.R.D., Alves, R.R.N., 2011 Perceptions of environmental changes and Lethargic crab disease among crab harvesters in a Brazilian coastal community. J. Ethnobiol. Ethnomed. 7, 34.

Firmo, A.M.S., Tognella, M.M.P., Silva, S.R., Barboza, R.R.R.D., Alves, R.R.N., 2012 Capture and commercialization of blue land crabs ("guaiamum") Cardisoma guanhumi (Lattreille, 1825) along the coast of Bahia State, Brazil: an ethnoecological approach. J. Ethnobiol. Ethnomed. 8, 12.

Glaser, M., 2003. Interrelations between mangrove ecosystem, local economy and social sustainability in Caeté Estuary, North Brazil. Wetl. Ecol. Manag. 11, $265-272$.

Glaser, M., Grasso, M., 1998. Fisheries of a mangrove estuary: dynamics and interrelationships between economy and ecosystem in Caeté Bay, North-Eastern Pará, Brazil. Boletim do Museu Paraense Emilio Goeldi. Zoologia 14, 95-125.

Goodman, L.A., 1961. Snowball sampling. Ann. Math. Stat. 32, 148-170.

Hamilton, L., Dixon, J., Miller, G., 1989. Mangroves: an undervalued resource of the land and the sea. Ocean. Yearb. 8, 254-288.

IBAMA - Instituto Brasileiro do Meio Ambiente e dos Recursos Naturais Renováveis, 2003a. Portaria no 034/03-N, 24/06/2003. [Ordinance \# 034/03-N, 24/06/2003] (In Portuguese).

IBAMA- Instituto Brasileiro do Meio Ambiente e dos Recursos Naturais Renováveis, 2003b. Portaria $n^{\circ} 52,30 / 09 / 2003$ [Ordinance \#52/03-N, 24/06/2003] (In Portuguese).

IBGE- Instituto Brasileiro de Geografia e Estatística, 2010. Sinopse do Censo demográfico 2010. http://www.censo2010.ibge.gov.br/sinopse/index.php? $\mathrm{uf}=28 \&$ dados $=10$ (Accessed 10 January 2013). [Synopsis of the $2010 \mathrm{De}$ mographic Census]. (In Portuguese).

Johannes, R.E., 2002. The renaissance of community-based marine resource management in Oceania. Annu. Rev. Ecol. Syst. 33, 317-340.

Knoppers, B., Medeiros, P.R.P., Souza, W.F.L., Jennerjahn, T., 2006. The Handbook of Environmental Chemistry. The São Francisco Estuary, Brazil, pp. 51-70, 5-H.

Lacerda, L.D., 2002. Os manguezais do Brasil. [The mangroves of Brazil]. In: Vannucci, M. (Ed.), Os Manguezais e nós: uma síntese de percepções. Edusp, São Paulo, pp. 193-208.

Macintosh, D.J., 1982. Fisheries and aquaculture significance of mangroves swamps, with special reference to the Indo West Pacific region. In: Muir, J.F., Roberts, R.J (Eds.), Recent Advances in Aquaculture. Croom Helm, England, pp. 4-85.

Macnae, W. 1974. Mangrove Forest and Fisheries, FAO, Rome (IOFC: DEV).

Magalhães, H.F., Neto, E.M.C., Schiavetti, A., 2012. Local knowledge of traditional fishermen on economically important crabs (Decapoda: Brachyura) in the city 
of Conde, Bahia state, northeastern Brazil. J. Ethnobiol. Ethnomed. 8, 13.

Magris, R.A., Barreto, R., 2010. Mapping and assessment of protection of mangrove habitats in Brazil. Pan Am. J. Aquatic Sci. 5, 546-556.

Marques, J.G.W., 1991. Aspectos ecológicos na etnoictiologia dos Pescadores do Complexo Estuarino-Lagunar Mundaú-Manguaba [Ecological aspects in etnoichthyology of fishermen from the Mundaú-Manguaba Estuarine-Lagoon Complex]. PhD Thesis. State University of Campinas, Campinas, Brazil (In Portuguese).

Matthes, H., Kapetsky, J.M., 1988. Worldwide compendium of mangrove-associated aquatic species of economic importance. FAO Fish. 675-683.

Mendonça, J.T., Machado, I.C., 2010. Mangrove oyster (Crassostrea spp.) (Sacco, 1897) extractivism in Cananéia estuary (São Paulo, Brazil) from 1999 to 2006: capture and management evaluation. Braz. J. Biol. 70, 65-73.

Nascimento, D.M., Ferreira, E.N., Bezerra, D.M., Rocha, P.D., Alves, R.R.N. Mourão, J.S., 2012. Capture techniques' use of Caranguejo-uçá crabs (Ucides cordatus) in Paraíba state (northeastern Brazil) and its socio-environmental implications. An. Acad. Bras. Ciências 84, 1051-1064.

Nascimento, D.M., Alves, A.G.C., Alves, R.R.N., Barboza, R.R.D., Diele, K., Mourão, J.S. 2016. An examination of the techniques used to capture mangrove crabs, Ucides cordatus, in the Mamanguape River estuary, northeastern Brazil, with implications for management. Ocean Coast. Manag. 130, 50-57.

Nfotabong-Atheull, A., Din, N., Essomè Koum, L.G., Satyanarayana, B., Koedam, N., Dahdouh-Guebas, F., 2011. Assessing forest products usage and local residents perception of environmental changes in peri-urban and rural mangroves of Cameroon, Central Africa. J. Ethnobiol. Ethnomed. 7, 41.

Nishida, A.K., Nordi, N., Alves, R.R.N., 2006a. The lunar-tide cycle viewed by crustacean and mollusc gatherers in the State of Paraíba, Northeast Brazil and their influence in collection attitudes. J. Ethnobiol. Ethnomed. 2, 1.

Nishida, A.K., Nordi, N., Alves, R.R.N., 2006b. Molluscs production associated to lunar-tide cycle: a case study in Paraíba State under ethnoecology viewpoint. J. Ethnobiol. Ethnomed. 2, 28.

Nishida, A.K., Nordi, N., Alves, R.R.N., 2006c. Mollusc gathering in Northeast Brazil: an ethnoecological approach. Hum. Ecol. 34, 133-145.

Nordi, N., Nishida, A.K., Alves, R.R.N., 2009. Effectiveness of two gathering techniques for Ucides cordatus in Northeast Brazil: implications for the sustainability of mangrove ecosystems. Hum. Ecol. 37, 121-127.

Ostrom, E., 2009. A general framework for analyzing sustainability of socialecological systems. Science 325, 419-422.

Pinheiro, M.A.A., Rodrigues, A.M.T., 2011. Crustáceos sobre-explotados e o Plano Nacional de Gestão dos caranguejos uçá (Ucides cordatus), guaiamú (Cardisoma guanhumi) e do siri-azul (Callinectes sapidus): uma estratégia para evitar que passem ao "status" de ameaçados de extinção. Rev. CEPSUL - Biodiversidade Conserv. Mar. 2, 50-57 [Over-exploited crustaceans and the National Management Plan for the crabs Uçá (Ucides cordatus), guaiamú (Cardisoma guanhumi) and blue crab (Callinectes sapidus): a strategy to prevent them from "threatened" to extinction status]. (In Portuguese).

Pinto, M.F., Mourão, J.S., Alves, R.R.N., 2015. Use of ichthyofauna by artisanal fishermen at two protected areas along the coast of northeast Brazil. J. Ethnobiol. Ethnomed. 11, 132.

PNUD - Programa das Nações Unidas para o Desenvolvimento, 2013. Atlas Brasi 2013 [ Atlas of Brazil 2013 ] (In Portuguese).
Primavera, J.H., 2006. Overcoming the impacts of aquaculture on the coastal zone. Ocean Coast. Manag. 49, 531-545.

Rocha, M.S.P., Mourão, J.S., Souto, W.M.S., Barboza, R.R.D., Alves, R.R.N., 2008. Uso dos recursos pesqueiros no Estuário do Rio Mamanguape, Estado da Paraíba, Brasil. Interciencia 33, 903-909 [Use of fishery resources in the Mamanguape River Estuary, Paraíba State, Brazill (In Portuguese).

Rönnbäck, P., 1999. The ecological basis for the economic value of mangrove forests in seafood production. Ecol. Econ. 29, 235-252.

Saenger, P., 2002. Mangrove Ecology, Silviculture and Conservation. Kluwer Academic Publishers, Dordrecht, London.

Santos, L.C.M., Matos, H.R., Schaeffer-Novelli, Y., Cunha-Lignon, M., Bitencourt, M.D., Koedam, N., Dahdouh-Guebas, F., 2014. Anthropogenic activities on mangrove areas (São Francisco River Estuary, Brazil Northeast): a GIS-based analysis of CBERS and SPOT images to aid in local management. Ocean Coast. Manag. 89, 39-50.

Santos, L.C.M., Rollo Jr., M.M., Costa, T.M., Pinheiro, M.A.A., Dadouh-Guebas, F. Bitencourt, M.D., 2016. Spatial analysis of a coastal area for conservation and fishery of mangrove edible crab (Ucides cordatus). J. Coast. Res. 75, 685-689.

Satyanarayana, B., Mulder, S., Jayatissa, L.P., Dahdouh-Guebas, F., 2013. Are the mangroves in the Galle-Unawatuna area (Sri Lanka) at risk? A social-ecological approach involving local stakeholders for a better conservation policy. Ocean Coast. Manag. 71, 225-237.

Sergipe, Governo do Estado, 2004. Decreto n. ${ }^{\circ} 22.995$ de 09 de novembro de 2004. [Decree \# 22.995 of $9^{\text {th }}$ November, 2004] (In Portuguese).

Souto, F.J.B., 2007. Uma abordagem etnoecológica da pesca do caranguejo, Ucides cordatus, Linnaeus, 1763 (Decapoda: Brachyura), no manguezal do Distrito de Acupe (Santo Amaro-BA). [An ethnoecological approach of the crab fishing, Ucides cordatus, Linnaeus, 1763 (Decapoda: Brachyura) in Acupe District mangrove (Santo Amaro, Bahia)]. Biotemas 20, 69-80 (In Portuguese).

Souto, F.J.B., 2008. A ciência que veio da lama: etnoecologia em área de manguezal. [The science that came from the mud: ethnoecology in mangrove area]. NUPEEA, Recife (In Portuguese).

Spalding, M., Kainuma, M., Collins, L., 2010. World Atlas of Mangroves. Earthscan, London, Washington, DC. ISBN 978-1-84407-657-4.

Sturtevant, W.C., 1964. Studies in ethnoscience. Am. Anthropol. 66, 99-131.

Vannucci, M., 2002. Os Manguezais e nós: uma síntese de percepções. [The mangroves and us: a synthesis of insights]. Edusp, São Paulo (In Portuguese).

Walters, B.B., 2003. People and mangroves in the Philippines: fifty years of coastal environmental change. Environ. Conserv. 30, 293-303.

Walters, B.B., Rönnbäck, P., Kovacs, J.M., Crona, B., Hussain, S.A., Badola, R., Primavera, J.H., Barbier, E. et al., 2008. Ethnobiology, socio-economics and management of mangrove forests: a review. Aquat. Bot. 89, 220-236.

Ward, D., Ngairorue, B.T., Apollus, A., 2000. Perceptions and realities of land degradation in arid Otjimbingwe, Namibia. J. Arid Environ. 45, 337-356.

Warner, G., 1997. Participatory management, popular knowledge, and community empowerment: the case of sea urchin harvesting in the Vieux-Fort area of St. Lucia. Hum. Ecol. 25, 29-46.

Wattage, P., Mardle, S., 2005. Stakeholder preferences towards conservation versus development for a wetland in Sri Lanka. J. Environ. Manag. 77, 122-132.

Zann, L.P., 1999. A new (old) approach to inshore resources management in Samoa. Ocean Coast Manag. 42, 569-590. 